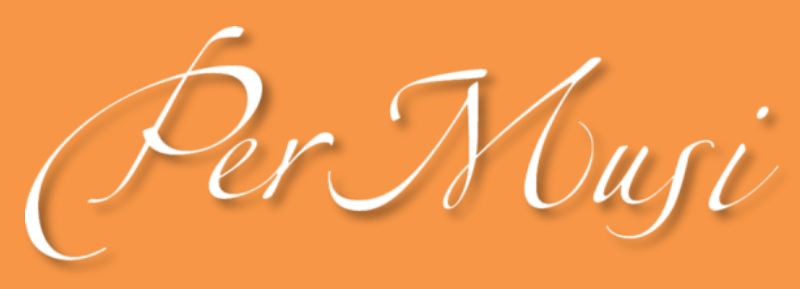

eISSN 2317-6377

\title{
What does gender have to do with music, anyway? mapping the relation between music and gender
}

\author{
Ann Werner \\ https://orcid.org/0000-0002-2540-8497 \\ Linnaeus University, Department of Media and Journalism \\ ann.werner@Inu.se
}

SCIENTIFIC ARTICLE.

Submitted date: 10 Dec 2018.

Final approval date: 14 Mar 2019

\begin{abstract}
What does gender have to do with music?', is in this article a question explored in order to 1) give an overview of important themes and areas in feminist interdisciplinary research on music and gender from the past decades, and to 2) theoretically advance what is specific about music's relation to gender, and discuss how music and gender research can be furthered today. To achieve these two aims, the author describes and discusses different approaches to investigating the relation between music and gender; cultural critique of music itself, consumption/production research, studies of genre and social settings as well as studies of media technology. The author, with her portrayal of the field as a back-drop, wants to revitalize a discussion of the strengths and weaknesses of music and gender research.Arguing that this is an interdisciplinary field with its own theoretical contribution that can be furthered by advancing the discussions of music's particularity and music research's relation to intersectional gender theory.
\end{abstract}

Keywords: Gender and music; feminist research; interdisciplinary and intersectionality in music.

\section{O QUE GÊNERO E MÚSICA TEM EM COMUM, ENTÃO? MAPEANDO A RELAÇÃO ENTRE MÚSICA E GÊNERO}

Resumo: A pergunta "o que o gênero tem a ver com a música?" é explorada neste artigo com intuito de: 1) fornecer uma visão geral de temas e áreas importantes da pesquisa interdisciplinar feminista sobre música e gênero das últimas décadas; 2) avançar teoricamente naquilo que é específico sobre a relação da música com o gênero e discutir como a pesquisa sobre música e gênero pode ser promovida atualmente.Para atingir esses dois objetivos, a autora descreve e discute diferentes abordagens para investigar a relação entre música e gênero: crítica cultural da música em si; pesquisa sobre consumo / produção; estudos de gênero e contextos sociais, bem como estudos de tecnologia de mídia.A autora, com seu retrato do campo como pano-de-fundo, quer revitalizar a discussão sobre os pontos fortes e fracos da pesquisa sobre música e gênero.Argumenta-se que este é um campo interdisciplinar com sua própria contribuição teórica que pode ser promovido avançando nas discussões sobre a particularidade da música e a relação da pesquisa musical com a teoria do gênero interseccional.

Palavras-chave: Gênero e música; pesquisa feminista; interdisciplinaridade e interseccionalidade em música.

(C) (1) 


\section{What does gender have to do with music, anyway? mapping the relation between music and gender}

Ann Werner, Linnaeus University, ann.werner@Inu.se

\section{Introduction}

Students have asked me in class, scholars I've met at conferences have asked, new acquaintances at parties have asked: what does gender have to do with music anyway? This question is generally asked in a curious but disbelieving tone of voice.Implying that gender, to the person asking, has nothing to do with music.Sometimes the question is embedded in an anti-genderist agenda, believing that gender studies and gender equality politics have gone "too far" and may even be a conspiracy (Hark 2017, 20).Levels of suspicion against gender research and the scholars that utter the word (gender) are far more common in academia than one might think, ranging from post-feminsm; the belief that "this was dealt with in the 70 's/80's", to positivism; the belief that "research should be separated from political thought and can be objective", and the before mentioned anti-genderist agenda.Still, some of the people asksking have nothing against gender studies, they may even be feminist scholars in the social sciences.They are instead speaking from another discursive repertoar based on ideas about what music is.In this thought formation music cannot be a political arena since music is "good", a field of aestethic beauty and affective enjoyment for practicioners and listener, free from the dirty messiness of social interaction.

While understanding the ideas the question may come out of, to a feminist interdisciplinary scholar who has been researching gender, music and media for some time the question (What does gender have to do with music?) is still annoying on an emotional level.Sometimes even infuriating, because not only does it undermine my area of study, it usually does so publically while I am holding a lecture, presenting a paper or describing my work in a social setting.Because of the perceived ignorance and scorn in the question I have previously not considered it thoroughly, I have tried to swiftly answer and move on, to get away from the person asking.In this article, I take a different approach: I try to answer the question properly from my own situated position and my knowledge of research on music and gender.

Doing so means revisiting the scholarly texts on music, gender and power that have inspired me, comparing their starting points, approaches to the subject and conclusions with each other.Also, it requires that I address both what music has in common with other cultural and mediated expressions and what may be unique for music.I don't claim to be the first researcher to address the relationship between gender and music in a systematic way, McClary (1991), Whiteley (1997), Kearney (2017) and Hawkins (2017) have written excellent outlines of music and gender research, monographs and anthologies, from slightly different disciplinary positions within musicology and cultural studies.But, as I will demonstrate, a condensed answer to the question in article-form can be of value for scholars and students in adjoining 
fields and it can further the theoretical discussion on music and gender.The aim being to start discussions in the field of music and gender research, and inspire debates, in which we do not have to always agree.

Before I start out, I want to clarify that while not all the work cited here employs intersectional understandings of gender, I do.In intersectional gender theory dimensions of power such as gender, race, class and nation are understood as always intra-acting with each other, articulating the cultural and social in this intra-action (Collins 1998).Gender itself is seen as ideas and structures of femininity and masculinity - not as physical cis men/women. With this said, not all the work I refer to here goes beyond the gender binary, or takes racism or class privilege into account in analysis, and I will return to discuss what intersectional studies of music and gender can be in the conclusion.Also important to keep in mind, is that the references and fields presented here are shaped by my education, in western and English-speaking interdisciplinary research traditions; cultural studies as well as musicology, media studies and gender studies.It should be seen as a situated description and discussion of the relationship between music and gender and not as a general or universal one.Adding other descriptions and discussions to mine will enrich the field and futher it theoretically and empirically.

The article starts out discussing how music can be understood as text or discourse, and be a target of feminist cultural critique as such, it further discusses how consumption; uses of music and taste, as well as production and industry can be studied as gendered practices.After that the organization of music in genres, and social arenas, which have been analyzed in terms of gender, and media technology developments as a non-discursive power aspect in the field of music are discussed.Finally, the specificity of music, and the specificity of music and gender as a field of study emerging from the research themes presented in the article are summed up and discussed as motif for further intersectional studies of music and gender.l am here hoping to convince all of those who have asked me what gender has to do with music of the importance of this research.

\section{Music as meaning, discourse or text}

Representation, language and discourse have been analyzed by scholars applying cultural critique in order to discuss the meaning and value of cultural texts.Fornäs (2013) has argued that cultural critique can be divided into five types; negative, aesthetic, philosophical, political and communicative. While all five forms of critiques have shaped the ways in which feminist scholars discuss music, the political critique, focusing on unjust power relations in cultural texts and taking inspiration from the Frankfurt school's approach to culture (Fornäs 2013, 505), is a strong influence for feminist analysis of music.Applying a theoretical perspective that regards cultural texts as creating (political) meaning - rather than just reflecting the intentions of the author, or the object they portray, has been a dominant way of understanding culture and popular culture in the humanities since the 1970's (Storey, 2015).Texts, in this way of seeing them, are not neutrally meaningful: meaning always contains dimensions of power, and feminist scholars from different disciplines have taken on the task to look closer at music as a type of meaningful text in terms of gender, race and class etcetera.

McClary's (1991) feminist critique of the field of (North American) musicology was an early effort to uncover the structures of gender and sexuality in musical content.Inspired by the development in gender theory during the late 1980's and what they might mean for analyzing music she argues that music constructs gender and sexuality, thus, it can be analyzed and critiqued as gendered discourse (Mcclary 1991, 7).Discussing Bartok and Monteverdi, as well as Laurie Anderson and Madonna, McClary famously 
paid interest to the structure of sounding music itself as well as lyrics, plots and stage representations of gender and sexuality in classical music, avant-garde music and popular music.Many have been inspired by her efforts, and more recently James (2015) has closely analyzed contemporary popular music arguing that recent trends in the genres pop and electronic dance music (EDM) displays forms of new gendered understandings of the world marked by feminist advancements as well as neoliberal discourse.By investigating contemporary mainstream (mainly North-American) artists and songs James (2015, 136) argues that in pop music today neoliberal feminist ideas have taken hold in musical structure as well as lyrics and artist's performances, often in terms of performed resilience, illustrated by James with amongst others Lady Gaga.James argues that individual overcoming (as opposed to collective struggle) is promoted in today's resilient popular music as a neoliberal reaction to unequality in terms of gender and race.

While McClary (1991) and James (2015) have both contributed to the field with thorough feminist critical analysis of gender, sexuality, race and music, a public discussion on what the gendered content in music actually means has also colored previous decades. Heavy Metal bands have in public debate been seen as seductive (and destructive) for young white girls in the 1980's, also Hip Hop has been discussed as misogynistic or violent, destroying black North-American youth (often male) in the 1990's and onward.These are only two examples of such topics of public debates.In these debates, the content and meaning of music, in terms of for example gender, sexuality, class and race, is often understod as having a direct effect on its audience, specifically a young audience described as impressionable and vulnerable.The practices, uses and tastes of said audience has also been a field of research examined by feminist scholars often coming out of music sociology or cultural studies.

\section{Uses and taste}

Consumption of music, and the contructions of gender, has been studied in music sociology, cultural studies and youth studies by researchers paying interest to the young feminine consumer and her tastes and practices.Commonly this research does not assume that music simply affects its users, or that meaning can be found in the music itself, but that music consumption is a part of identity formation and social life and music therefore takes on different meanings in peoples' use of it, in cultural practice.This approach to music and gender was in the UK a reaction to the focus on young men and class in youth studies and subculture research.McRobbie (1980) discussed the bias of cultural studies at the time, highlighting how a focus on public space and visibility had shaped the discussions of music culture into a discussion about young men's music culture: paving a way for research on girls and femininity within subculture research and addressing the masculine canon in the UK.Arguing that subculture research of the time was focusing on young men, without examining their misogyny, their constructions of gender as such, or addressing the absence of women, McRobbie $(1980,17)$ concludes that subcultural research had something to offer about gender and music culture, but that researchers had chosen not to focus on this angle.Discussion on music and gender can, according to McRobbie, be further analyzed in young men's cultural practices through the lens of feminist theory. While McRobbie $(1980,17)$ also argued that research on girls/feminine subjects', not only young men's, uses of music must be developed in order to further knowledge of subulture's relationship to gender, she did not state that research on girls, to complement the research on boys, was a solution.Instead she suggested that there was a need for attention to gender structures, power and concequences of gendered youth culture in subcultural research. 
Since her article, many scholars have followed this advice, and I will only mention a few here.Baker (2004), for example, studied pre-teen girls' uses of music in after school care and their self-making when listening to, discussing and using music.By imitating older girls in musical play the participants in Baker's study were engaging in musical play as identity construction, expressing concern about the younger girls listening to muscic with lyrics alluding to sex was one way for Baker's participants to position themselves as in-theknow about sex.Baker $(2004,210)$ concluded that in musical play at a young age there were meaningful constructions of gender and sexuality, when the girls were graoing what it might meen to be a teenage girl and a sexual being.Werner (2009) has studied teenage girls uses of music online, file sharing and commenting on music on MSN Messenger as part of their everyday activities at home after school, investigating how ownership over technology and access to music was affected by gender relations in the home.In Werner's study (Werner 2009, 281) wheter the girls had brothers or not decided where the computer was placed in the home, and their access to it, girls with brothers had less access.At the time of study the computer was central for music use, since it was before the introduction of music streaming services on smartphones. While there are studies like Baker's and Werner's focusing on gender and music use in young girls' mundane everyday life (see also DeNora 2000 for a discussion on everyday life), fan studies has been an area in which the use of music and gender has been explored.Following subculture research, and post-subculture research, fan studies focus on the committed consumers devoting time, money and identity to a particular form of culture.

Hill $(2016,18)$ discusses how in public debate fandom has been perceived as something pathological, fans being too devoted, forming un-healthy attachments to popular culture fantasies.She also mentions that studies of music fan cultures often have focused on fans of one particular artist, like Bruce Springsteen, Kate Bush or Tori Amos, while she herself (HILL, 2016, p.28) is interested in female fans of the genres hard rock and heavy metal. While many of her conclusions are particular for these genres, the invisibility and devaluing of female/feminine fans that she finds resonate with how femininity in fandom is perceived more generally, with known figures like groupies, girlfriends, or teenyboppers being associated with feminine fandom. In this way Hill is discussing not only the discusrive formations among female/feminine users of music but also the discourses they have to relate to in their practices of music use.Trier-Bieniek (2012) who interviewed fans of Tori Amos also challenges such stereotypes of fans and femininity in her work by exploring how Tori Amos's fans finds strength and develop feminine and lesbian identities in listening to and talking about the music of their idol (TRIER-BIENIEK, 2012, p.26-29).Arguably, the type of artist and music genre the consumer prefers also take part in shaping what identities and practices are possible in terms of gender, sexuality, class and race, as well as what the fans bring with them into the consumption.Thus, the music is not responsible for the development of identity, but provides identity and social interactions with material, that may be more likely to form people in some ways than others.

\section{Production and industry}

On the other side of the consumption/production binary, feminist research on music and gender has focused on how music is made, how the music industry functions, how DJs and musicians work, and what this has to do with patterns of gender and power in culture and society (see Leonard 2007, for an overview).One strand of feminist musicology focuses on the contribution of female identified artists to music, their output and artist lives, and in that way adding them to the music canon, giving them a place in music history (Reddington 2007).Leonard (2007) investigates instead how gender is produced and maintained by institutions, discourses, individuals and groups within the music industry.Studies focusing on 
the production side of contemporary popular music have tended to empirically investigate small labels (Leonard 2007) or up-and-coming musicians to understand the work of gender in the music industry.Most likely, access becomes a problem for those who want to study major labels or super-stars.

Bayton (1998) studied female identified rock musicians ethnographically, and methodologically her work resembels some of the studies of uses and fans mentioned above.Also, Schippers (2002) investigated gendered patterns among female identified alternative hard rock musicians.Both Bayton and Schippers discusses how the musicians in their studies had to negotiate with both a masculine ideals about rock music identity, and negative stereotypes of femininity, negotioatins that presented challenges to female identified rock musicians trying to make it in the music business.Ultimately making their career paths difficult, and some of them to consider giving up on being a musician.Arguably female identified, but also queer/trans persons, striving to work as musicians, DJs or music producers often have to transcended or negotiated the idea of masculinity and heterosexuality integral to their work.In research on DJs these negotiations have been concluded to happen in for example the relationships to machines and technology, as well as in the gendering of sound, and audio-stereotyping of feminine/queer DJs (Gadir 2017).In regards to electronic dance music DJ culture and gender, female/feminine networks for DJs (Farrugia 2012) and how female identified DJs negotiate their profession, musical selection, identity and technology has been studied (Gavanas and Reitsamer 2013).

Within music education studies the research on gender and music production has taken a slightly different focus than the studies mentioned coming out of cultural studies or music sociology using musicological approaches and education theory.Paying interest to the gendering of music production, or more broadly musicking, in educational settings in schools Armstrong (2011) has concluded that today's music education relies on technological innovation for music production and that practices around these take part in increasing the gendering of music education, rather than creating a democratic improvement for all pupils in school.Accoring to her the masculine value related to technology diminishes girls' chances on the production side of music education.In a different setting Björck (2013) has researched rock schools for girls and what ideas about gender and feminism are constructed in all-girl educational music settings.She discusses individualization of success as well as failure and the significance of this idea as important themes for contemporary music education.Further, instruments have been analyzed as possible vehicles of gendering music education in schools (Bergman 2009), as well as for rock musicians and upcoming bands (Bayton 1998), so has the curriculum of music education and how it is presented (Green 1997).The masculinization of guitars and percussion, and feminization of the flute and the harp, for example, are well researched and documented.The gendering of music production, and feminist research on music production, is a large field ranging from educational settings, record companies, to amateur and professional musicians/DJs. The focus on producing as an activity producing music, knowledge and gender at the same time is the common denominator.After discussing consumption and production I will move on to discuss structures of ideas and the meaning of musical infrastructure, rather that activities and practices, acknowledging that these dimension always interact with each other.

\section{Genre and the social organization of music}

The feminist critique of music, lyrics, sounds and performance, has been an approach shaping the feminist discussion on music, as noted in the second section of this article.But scholars have also chosen to address the organization of music and sound as part of how music is a gendered cultural form, creating differences 
and power imbalances in culture and society.Taking issue with simplified ideas that one genre of music might be 'bad' (bad taste, or bad for you), and the naturalization of boundaries around genres, feminist studies of genres tend to discuss how intersecting power dimensions shape the boundaries of musical genres and their value.Cohen (2001) has discussed the relationship between gender and the construction of the genres rock and pop, arguing, that genres are constructed systems for ordering music, no more natural than ideas about gender as such, and created through genre performance.Pough (2004, 61; see also, Perry 2004), while discussing black women in hip hop, has also argued that while hip hop, part of black North American popular culture, might welcome certain female performers it can still be marginalizing black women. Hip hop (Pough 2004, 87) being a genre shaped by race, as well as gender, places female rappers in a particular predicament: while black women always have been part of the hip hop continuum using it as positions of strength, they are sometimes marginalized because of the masculine dominance in the genre.For hip hop, as genre, R\&B and popular chart versions of hip hop mixed with pop are treated as the feminized counterpart, and in these genres there are more women performers.And while all related genres are heavily racialized, seen as 'black' music, this has not prevented white artists to reach success using sounds and styles of the genres, as in the case of Eminem, Iggy Azalea or Justin Timberlake: leading to interesting discussions of apporpriations of black culture in North America and beyond.Railton (2001), in discussing pop's location on the feminine side of the genre dichotomy pop/rock, argues that the most popular chart pop is feminized as a genre, this does not mean that men can't perform pop, but rather that mainstream chart pop, the genre as a whole, is devalued by its proximity to femininity associated with frivolous and shallow culture, using the same rhetoric used to devalue women, and the audience perceived to listen to this music.However, Ganetz $(2017,414)$ argues differently when she concludes that mainstream pop can open up for destabilizing heteronormativity, not being firmly connected to one idea about gender and sexuality, as some forms of rock are connected to masculinity and heterosexuality. Her argument (Ganetz 2017), with foundation in her empirical studies of reality music TV, is that the type of feminization shaping the genre 'pop' is not stable in its construction of gender and sexuality, but rather opens up for queer artists and identities, and transformations of normativity in popular culture.

Furthermore, the way the organization of music in genres is shaped by ideas about gender, race, sexuality and class etcetera also interacts with the social organization of music related activities.Debates about the "womyn born womyn" policy of the Michigan Womyn's festival is one example of this, the festival has in policy created certain boundaries for what a woman and a feminist can be.Hayes discusses how the protests against the policy included both trans women and black women, pointing out that norms around both gender and race were created in the social space of the festival (Hayes 2010, 164).Music related contexts and activities; clubs, concerts, music education, music magazines, fan communities, etcetera, are organized in conversation with how genres are structured, and how social life is organized, usually abiding by rules of class, race and gender divisions.DeNora $(2000,125)$ has argued that music is a material of social organization, called upon in subjects' way of acting in social settings and as such it can be pre-scriptive of social order(s).While DeNora is talking about social orders on a macro level, I would argue that the social organization of music activities can be said to be modelled from larger social patterns, and musical patterns therefore often act in sync with power and social order(s) in society.Interpelling music consumers and producers to be organized in line with expectations.For example: in music education divisions in genres and instruments often interplay gendered and racialized logic, where some genres, activities and instruments are re-constructed as feminine, white, black, and so on (Green 1997).Similar patterns can be 
found in the organization of fan communities where certain groups and genres are implicitly speaking to, for example, young girls (Railton 2001).Also, in social spaces where music is consumed - such as concerts and clubs - divisions of genre as well as race, class and gender are often enacted.This happens in terms of venues, entrance fees, the organizing of the space itself, but also in the performance and choice of the artist or band invited. The logics of race and class in organizing festivals can be seen in public debate about some acts drawing the 'wrong' audience to a festival.Some hip hop acts would be perceived as drawing violent, working-class and/or racialized men, for example.There has also been discussions in the past years about the widespread sexual harassments of female identified visitors to music festivals, in Sweden this has lead to the founding od a music festival where cis men are not welcome (Statement festival in Gothenburg).

While social order(s), and their manifestations in genres, play a significant role in in music activities, there is no deterministic relationship between gendered/racialized orders, music genre and social activities around music.Taylor (2012) has, in her investigation of queer music culture, concluded that musical performance and music watching can be made into very different things in the social setting of LGBT spaces, exemplifying a space where social organizing of music not necessarily follow a strict logic of genre gender, race and class.Innovations in genre, another example of when traditional genre organization is put into play, has been labelled hybridity in music, and can occur when musical traditions from other places than the West meet Western popular musics and new genres, like commercial bhangra is developed (Manuel 1993, 179).Hybrid music can be understood as an aesthetic effort to transgress traditional boundaries structured in difference and power within music's organization.Often used to describe music transgressing previous genre divisions hybrid music, however, tend to create new genres or subgenres that in time is organized into a gendered and raced system of music, bhangra did for example develop into a (gendered and racialized) genre of its own rather rapidly after transgressing and challenging genres and racialized identity in the UK and India. While the systematization and organization of music in genres and social activities has proved a rich field of gendered practices, the role of technology is another area of interest bridging consumption and production binaries, especially after the digitalization of music culture.

\section{Media technology}

The medatization of music culture, and media technologies' importance for music, has been another field of study for feminist scholars researching gender and music. While one can argue that music is always mediated, through the somatechnological tool of the voice, through instrument use, the Internet and digital production technologies have accelerated media's importance to music culture and music research in the past decades.Coates (1998) studied what happened in discussions about gender and rock on ROCKLIST, an online discussion forum for rock music.She argued that the response to bringing up genderbased power relations in rock music turned out to be repetitions of said patterns of power in online communities surrounding music.Internet discussions, thus, was in her case repressing critical debates about gender in music culture rather than encouraging them.Coates and other feminist media scholars have been investigating the idea that the Internet is an equalizing agent for popular music, making it available and the same to all.

Following the development of media technology's role in music culture, feminist scholars have payed attention to how other digital media technology than the Internet, like computers and production technology, software and hardware, interplay with gender and music culture.Armstrong (2011) has already 
been mentioned as an example of a scholar taking a science and technology studies perspective on music, education and gender.While Gadir (2017), also mentioned before, investigate the social role of DJ technology and how it contributes to the gendered patterns of DJ culture.Another field of study has been web sites and streaming services for music, like YouTube (Werner 2018).In her research on YouTube Werner has been focusing on the interplay between consumer, producer and technology in the creation of gendered online content.Concluding that DIY viral videos of dancing and singing are both a contribution to amateur musicking, and to gender constructions, that is embedded in the software infrastructure of YouTube as well as contextualized by the comments and likes the video gets. These different elements of production, reception and technological infrastructure (built by algorithms) genders music in a way that is in its form new, but in some cases strengthen and reproduce old ideas and stereotypes. Werner discusses som notable viral videos; Gangnam style and Harlem shake, partly because of their viral domince as a message of its own.And partly because of the negotiations of race and gender in the parodic repetitions of these dances and music videos.The role of technology, and in the examples taken here digital media technology, is therefore possible to be imagined as co-creator of what meanings gender, race etcetera can take on, rather than a channel for ideas about gender.

\section{Media technology}

Returning to the first paragraph of this article, I hope that I have beyond doubt convinced the reader that gender indeed has something to do with music.Many aspects of music have, in the research discussed here, been proven to be re-constructing, and de-constructing, ideas about femininity and masculinity, as well as race, sexuality, class etcetera.There are also some interesting tendencies in the research presented and discussed above. While feminist critique of music itself (sound, lyrics and performance) and studies of fans and consumers seem to often (not always) focus on music known to and listened to by many, studies of gender and music production more commonly focuses on alternative scenes; like alternative rock or electronic dance music.This tendency may have many explanations, for example access problems that would likely occur when researcher try studying the production processes of mainstream pop stars. While the studies of mainstream and alternative scenes both contain feminist cultural critique the division of attention, however, can be interpreted as speaking to an idea of the mainstream as mass culture to be critiqued and the aesthetic alternatives as (more often) transgressive music practices to be investigated.

The way that feminist research on music and gender is structured in this article divides it into research on content, consumption, production, organization and technology.A division displaying certain perspectives and studies, without claims to cover all research relevant for the field.Following the structure you will have noticed that the latter two focus on infrastructures that shape content or practices, rather than content or practices in themselves.Also, the two latter sections of the article answer the question about what is particular about music compared to other cultural forms.Music socially organizes many parts of life, permeates most peoples' everyday experience and through media technology can today be heard and produced by many, and in most places.Furthermore, the sound of music- the affect of noise on our bodies - is particular for music.And while affect and intensities of music has not been much discussed by feminist researchers in the area of music and gender, this can be explored more in the future.

In order to understand music's specificity as a cultural form and how it relates to gender I here want to propose a strengthening of the intersectional perspectives in studies of music and gender.Music and gender research is an interdisciplinary field where intersectional gender theory could be applied to further 
knowledge, not only in the field of identity practices among consumers and producers.By taking power dimensions such as race, class and sexuality into account more often as intra-acting factors - not other subjects - music and gender research could strengthen its arguments. Intersectional gender theory can also be used as inspiration for questions and topics to explore further, the practices of pop singers as musicians in their own right, the activities of fans of Rihanna and other racialized mainstream artists, male fans of mainstream popular music and so on.Intersectional gender theory would here speak to how research questions are formulated, how technology and genre can be taken into account as intra-acting in the formations of gender, race, sexuality and class etcetera in music culture.

\section{References}

Armstrong, Victoria.2011.Technology and the Gendering of Music Education.Farnham: Ashgate.

Baker, Sarah.2004."'It's Not about Candy': Music, Sexiness and Girls' Serious Play in After School Care". International Journal of Cultural Studies 7 (2): 197-212.

Bayton, Mavis.1998.Frock Rock: Women Performing Popular Music.Oxford: Oxford University Press.

Bergman, Åsa.2009.Växa Upp med Musik: Ungdomars Musikanvändande i Skolan och på Fritiden.Diss.Gothenburgh: University of Gothenburg Press.

Björck, Cecilia.2013.“A Music Room of One's Own: Discursive Constructions of Girls-Only Spaces for Learning Popular Music”. Girlhood Studies 6 (2): 11-29.

Coates, Norma.1998."'Can't We Just Talk about Music?': Rock and Gender on the Internet”.In: Mapping the Beat: Popular Music and Contemporary Theory, edited by Thomas Swiss, John Sloop and Andrew Herman, 77-99.Malden, Mass: Blackwell Publishers.

Cohen, Sara.2001."Popular Music, Gender and Sexuality".In: The Cambridge Companion to Pop and Rock, edited by Simon Frith, Will Straw and John Street, 226-242.Cambridge: Cambridge University Press.

Collins, Patricia Hill.1998. "It's All In the Family: Intersections of Gender, Race and Nation".Hypatia 3 (13): 62-82.

Denora, Tia.2000.Music in Everyday Life.Cambridge: Cambridge University Press.

Farrugia, Rebekah.2012.Beyond the Dance Floor: Female DJs, Technology and Electronic Dance Music Culture.Bristol: Intellect.

Fornäs, Johan .2013. The Dialectics of Communicative and Immanent Critique.tripleC 3 (11): 504-514.

Gadir, Tami.2017.“'I don't Play Girly House Music': Women, Sonic Stereotyping and the Dancing DJ".In: The Routledge Research Companion to Popular Music and Gender, edited by Stan Hawkins, 196-210.Oxon: Routledge.

Ganetz, Hillevi.2011.“Fame Factory: Performing Gender and Sexuality in Talent Reality Television”.Culture Unbound no.3: 401-417.

Gavanas, Anna and Rosa Reitsamer.2013.“DJ Technologies, Social Networks and Gendered Trajectories in European DJ Cultures".In: DJ Culture in the Mix: Power, Technology and Social Change in Electronic Dance Music, edited.by Bernardo Alexander Attias, Anna Gavanas and Hillegonda Rietveld, 5178.London: Bloomsbury.

Green, Lucy.1997.Music, Gender, Education.Cambridge: Cambridge University Press. 
Hark, Sabine.2017.Gender - Merely a "Social Fact": The Construction of Neo-Authorian Us/Them Dicothomies.Baltic Worlds no.3: 18-25.

Hawkins, Stan.2017.The Routledge Research Companion to Popular Music and Gender.Oxon: Routledge.

Hayes, Eileen M.2010.Songs in Black and Lavender: Race, Sexual Politics and Women's Music.Urbana: University of Illinois Press.

Hill, Rosemary Lucy.2016.Gender, Metal and the Media: Women Fans and the Gendered Experience of Music.London: Palgrave Macmillan.

James, Robin.2015.Resilience and Melancholy: Pop Music, Feminism and Neoliberalism.Alresford, Hants: Zero Books

Kearney, Mary Celeste.2017.Gender and Rock.New York: Oxford University Press.

Leonard, Marion.2007.Gender in the Music Industry: Rock, Discourse and Girl Power.Aldershot: Ashgate.

Manuel, Peter.1993.Cassette Culture: Popular Music and technology in North India.Chicago: University of Chicago Press.

Mcclary, Susan.1991.Feminine Endings: Music, Gender and Sexuality.Minneapolis: University of Minnesota Press.

Mcrobbie, Angela.1980.Settling Accounts with Subculture: A Feminist Critique.Screen Education no.34: 111-123.

Perry, Imani.2004.Prophets of the Hood: Politics and Poetics in Hip Hop.Durham: Duke University Press.

Pough, Gwendolyn.2004.Check it While I Wreck it: Black Womanhood, Hip Hop Culture and the Public Sphere.Boston: Northeastern University Press.

Railton, Diane.2001.The Gendered Carnival of Pop.Popular Music 20 (3): 321-331.

Reddington, Helen.2007.The Lost Women of Rock: Female Musicians of the Punk Era.Aldershot: Ashgate.

Schippers, Mimi.2002.Rockin Out of the Box: Gender Maneuvering in Alternative Hard Rock.New Brunswick: Rutgers University Press.

Storey, John.2015.Cultural Theory and Popular Culture: An Introduction. $7^{\text {th }}$ edition.London: Routledge.

Taylor, Jodie.2012.Playing it Queer: Popular Music, Identity and Queer World-Making.Bern: Peter Lang.

Trier-Bieniek, Adrienne M.2012.Sing Us a Song Piano-Woman: Female Fans and the Music of Tori Amos.Lanham: The Scarecrow Press.

Whiteley, Sheila.1997.Sexing the Groove: Popular Music and Gender.London: Routledge.

Werner, Ann.2009."Girls Consuming Music at Home: Gender and the Exchange of Music through New Media". European Journal of Cultural Studies 12 (3): 269-284.

Werner, Ann.2018."YouTube and Music Video Streaming: Participation, Intermediation and Spreadability".In: Streaming Music: Practices, Media, Cultures, edited by Sofia Johansson, Ann Werner, Patrik Åker and Gregory Goldenzwaig, 128-144.Oxon: Routledge. 